DOI: http://dx.doi.org/10.14393/che-v15n1-2016-2

DOSSIÊ: ARTIGOS

BILINGUAL EDITION: ENGLISH/PORTUGUESE

\title{
The discursive roots of the community: a genealogy of the curriculum (Bilingual edition: English/Portuguese)
}

As raizes discursivas da comunidade: uma genealogia do currículo

Las raíces discursivas de la comunidad: una genealogía del currículo

\author{
BARRY M. FRANKLIN ${ }^{1}$
}

\begin{abstract}
:
This article explores discourses constructed about the curriculum in the United States. The highlighted period goes from the 1890 s to the first thirty years of the $20^{\text {th }}$ century. Attention is given to the documents produced by the National Education Association (NEA) and the discursive formations outlined by three key individuals: Edward L. Thorndike, Ross L. Finney, and John Dewey. The main issue is about the curriculum as an effort to institute and perpetuate group living and the dispute around the idea of community.
\end{abstract}

Keywords: Curriculum, Community, Dewey, Thorndike, Finney.

\footnotetext{
${ }^{1} \mathrm{PhD}$ from the University of Wisconsin-Madison - Professor at the School of Teacher Education and Leadership Emma Eccles Jones College of Education and Human Services Utah State University - Major Fields of Interest: 4 curriculum policy, theory, and history urban education educational policy. E-mail: barry.franklin@usu.edu
} 


\section{Resumo:}

Este artigo explora discursos construídos em torno do currículo nos Estados Unidos. O periodo destacado se situa entre os anos de 1890 e os primeiros trinta anos do século XX. Destacam-se os documentos produzidos pela National Education Association (NEA) e as formações discursivas delineadas por três indivíduos chave: Edward L. Thorndike, Ross L. Finney e John Dewey. A questão central abordada diz respeito ao currículo como esforço de instituir e perpetuar a vida grupal e a disputa pela ideia de comunidade

Palavras-chave: Currículo, Comunidade, Dewey, Thorndike, Finney.

\section{Resumen}

Este artículo explora los discursos construidos en torno del currículo en los Estados Unidos. El período destacado se situa entre los años de 1890 y los primeros treinta años del siglo XX. Se destacan los documentos produzidos por la Asociación Nacional de Educación (NEA) y las formaciones discursivas delineadas por tres individuos clave: Edward L. Thorndike, Ross L. Finney y John Dewey. La cuestión abordada considera el currículo como el esfuerzo de instituir y perpetuar la vida grupal y la disputa por la idea de comunidad.

Palabras-clave: Currículo, Comunidad, Dewey, Thorndike, Finney. 
I.

One way of understanding educational policies and practices is to explore the discourses through which we frame their features. Such discourses represent "those textual ideas, concepts, and statements that not only provide meaning but constitute systems of power to affect social organization and human behavior" (Franklin, 2010, 8). They can include but are not limited to their origin and history, their purpose and mission, their ideology, their organization, their stakeholders, their interplay with other institutions, and their strengths and weaknesses.

The American curriculum is a case in point. Since a course or sequence of studyformal or informal - is a constitutive property of efforts to institute and perpetuate group living in succeeding generations, there may be no definitive, universally accepted starting point for such a consideration. We could begin our account with the efforts of seventeenth century Puritan settlers to provide for the socialization and tutelage of their children in the new American colonies. We might, however, focus our attention on the establishment of the mid-nineteenth common school movement. Or we could as a starting point look at the expansion of primary schools also early in the nineteenth century into different forms of secondary education.

My own preference for this essay is to launch my study during the decade of the $1890 \mathrm{~s}$ and continue looking through the first 30 or so years of the twentieth century. I have selected this period because these were the years that the urban, comprehensive high school, the institution that I have focused my attention on in most of my research, was shaped through the publication of reports that defined the nature, purposes, and structures that American secondary education would come to assume thereafter. Further, I have made this choice because this is more or less the period during which American educational reformers defined what I have argued is a key purpose for public schooling, in this country, the building of a sense of community among its citizenry.

The starting point for this essay is an examination of the discourses that framed the initial understanding that school reformers held of the comprehensive urban high school in the years surrounding the turn of the twentieth century. I have located the sites for these discourses in two National Education Association reports, the 1893 Report of the Committee of Ten (National Education Association, 1893) and the 1918 Commission on the Reorganization of Secondary Education's Cardinal Principles of Secondary Education Report (National Education Association, 1893). 
The importance of these reports for our purposes is that they provided a vision of the notion of community held by school reformers of the day. Having laid out the communitarian thinking subscribed to these by these reformers, I will look at how they organized the curriculum into a mechanism for building community. Here I will pay particular attention to the discursive formations framed by three key individuals, Edward L. Thorndike, Ross L. Finney, and John Dewey. Having explored these discourses, I will then turn to how they played themselves out in a number of concrete efforts for their in programs and proposals for the comprehensive high school. And finally, I will look at what our consideration of these discourses tells us about the state of the American curriculum. My account is not a traditional history with a linear trajectory that links the present curriculum with its supposed early origins. Rather the story that I will tell is more in the form of a genealogy in the Foucauldian sense of that term to highlight the important discourses that over time have came to the fore, retreated into the background, and reemerged again in the framing of the curriculum.

\section{II.}

The course of study in the first American high schools in the early nineteenth century represented an extension and expansion of the common school curriculum comprising work beyond that offered in the elementary grades. There were two configurations that this curriculum took. One was the classical curriculum, which had its roots in the educational ideas of Greece and Rome, the medieval university, and the Renaissance. In its original form it was comprised of the trivium (grammar, rhetoric and logic) and the quadrivium (arithmetic, geometry, astronomy, and music). The focus of this course of study as it appeared in the nineteenth century American; high school was on the classical languages of Latin and Greek and arithmetic. It was a program that was designed for the small number of students who were preparing to enter the university. There was a second and more popular configuration known as the English curriculum. Its roots lie in an effort to render the classical curriculum more practical and relevant to the world of commerce and business and included such socalled "modern subjects" as history, science, modern foreign languages, and literature. Some versions of the English curriculum also included subjects that had a vocational application including trigonometry and bookkeeping. In smaller, rural high schools it was not uncommon to find a course that included Latin along with many of the subjects that comprised the English course. (Angus \& Mirel, 1999; Krug, 1964; Tanner \& Tanner, 1990 
Proponents of the high school offered two rationales for these curricular patterns. One was the humanistic argument, which was most forcefully advanced by William Torrey Harris, who early in his career led the St. Louis Public Schools and later served as U.S. Commissioner of Education. He advocated a common curriculum comprised of subjects that offered students access to the key elements of the nation's Western heritage. These subjects constituted "windows of the soul" and represented the routes whereby students are infused with their cultural memory.

Arithmetic, he argued, conveyed our understanding of the quantitative, geography, our understanding of organic and inorganic nature; history, the will power of the nation; grammar, the inner workings of the mind; and literature and art, our guiding sentiments and convictions. Education for Harris was a process where the

Individual was to be socialized into the rules of the school and more broadly into the larger culture (Kliebard, 2004; Reese, 2000).

The second justification was that of mental disciplines. The purpose of the curriculum was to mental development. It was a viewpoint supported by the dominant psychological theory of the day, faculty psychology. According to this rational, the mind was seen as being comprised of any array of mental capacities such as reasoning, memory, observation, and judgment that could with proper training be developed. Much as we exercise the body to develop physical strength, we exercise the mind through the study of certain subjects, which according to its proponents turned out conveniently to be the disciplines that comprised the classical course (Kliebard, 2004; Ravitch, 2000).

An important feature of these curricular rationales was a view of the school program as an instrument for building a sense of community or common purpose among the American population. Community, however, is one of those concepts that is often labeled as a floating or empty signifier, to point to the fact that it is a word without a single or specific referent. The theologian Elizabeth Bounds (1997) has offered a number of what she calls "desires" to describe a search for community. They include a longing for like-mindedness and unanimity, a quest for a past and simpler time, and a wish to reclaim lost set of traditions in the face more dominant outlooks. She goes on quoting Rosemary Hennessy $(1993,14)$ to talk about the notion of community as "the array of sense making practices" that we employ to describe the existing reality. Community in other words is a term that is used in multiple ways to suggest with respect to schooling such "desirable goals...as working for the common good, 
cooperating with one's colleagues, [and] overlooking differences." It is a notion that fulfills "the role of joining individuals to collectivities of various sorts" (Franklin, 2010, 8, 9).

The Committee of Ten, which was organized in 1892 by the National Education Association, promoted this communitarian ideal in the view of the curriculum that they advocated. Their 1893 report called for four courses of study for the high schools - Classical, Latin-Scientific, Modern Languages, and English. Each of these programs included roughly the same pattern of courses in English, history, mathematics, and the natural sciences but differed in their foreign language requirements (Kliebard, 2004; Ravitch, 2000).

In preparing their report, the Committee addressed a number of key questions, the answers to which helped framed their recommendations. The most important of these questions for our purposes was whether a subject should be taught differently for students depending on their post-high school educational or career plans. The Committee said no. Every subject that is taught in secondary school, they argued, should be taught in the same way and to the same extent to all students (National Education Association, 1894; Reese, 2011). In answering this question in the way that they did, the Committee was asserting support for a common school ideal. Although such a principal has never between completely realized in US schools, it does advocate providing all children with the same educational experiences in the same settings (Franklin, 1994; Reese, 1988).

A communitarian theme was also embedded in the report of the Commission on the Reorganization of Secondary Education, The Cardinal Principles of Secondary Education. At the heart of this report was a set of seven objectives. These objectives - "health, command of fundamental processes, worthy home membership, vocation, citizenship, worthy use of leisure, and ethical character" (Commission on the Reorganization of Secondary Education, $1918,5)$ - were to be the goals that the would be provided to all students. The theme of community comes through most clearly in the report in the effort of its authors to link schooling to the ideals of democracy. Such ideals require that individuals and groups attain specialized vocational goals that are necessary for the progressive development of the nation while at the same time becoming unified. The report goes on to say that "without unification in a democracy there can be no worthy community life and no concerted action for necessary social ends" (Commission on the Reorganization of Secondary Education, 1918, 15).

The route for attaining these two ends, according to the authors of the report, was the comprehensive high school that provided "all curriculums in one unified organization." There were curriculum elements known as constants that would provide for the attainment of the 
seven goals of the high school. There were curriculum variables whose goal was to provide for the vocational needs of students. And there were to free electives to enable students to pursue their unique interests (Commission on the Reorganization of Secondary Education, 1918, 18-19). As the report's authors saw it, the comprehensive high school was the best mechanism for attaining the unification required in a democracy:

Through friendships formed with pupils pursuing other curriculums and having vocational and educational goals widely different from their own, the pupils realize that the interests which they hold in common with others are, after all, far more important than the differences that would tend to make them antagonistic to others. Through school assemblies and organization they acquire common ideas. Through group activities they secure training in cooperation. Through loyalty to a school, which includes many groups, they are prepared for loyalty to State and Nation. In short, the comprehensive school is the prototype of a democracy in which various groups must have a degree of self-consciousness as groups and yet be federated into a larger whole through the recognition of common interests and ideals (Commission on the Reorganization of Secondary Education, 1918, 20).

III.

As I noted earlier in this essay, American school reformers in the years around the turn of the twentieth century have used the notion of community in different and conflicting ways. Those of a conservative bent - the American psychologist Edward A. Thorndike (1874-1949) being a prime example - have used the term in an exclusionary manner to point to those characteristics that separate individuals and groups from each other including differences in language, religions, ethnicity, and culture. Talking about community in this way serves first to limit membership to certain individuals and groups and once that has been done to constrain, isolate, and even eliminate them. Although a feature of the notion of community that is viewed favorably by those who are within it and a part of it, it allows for its invocation to legitimate racism, sexism, and a host of other forms of control and exclusion. Thorndike and other early twentieth century American intellectuals used this understanding of the notion of community to oppose the increasing into the country of immigrants from Eastern and Southern Europe. They viewed this increased immigration as constituting a threat to the 
stability of American society and ultimately to democracy itself. For them, the idea of community was a defensive notion designed to curb the social disruption and dislocation that they identified with the growing diversity of the American population. To combat this threat they proposed efforts to restrict immigration. Beyond trying to prevent these immigrants from entering the country, they proposed using the schools and other social institutions as mechanisms of social control to instill in these immigrants what they perceived as correct values and attitudes. What they sought was a likeminded and homogenous American community rooted in the values, beliefs, and standards of behavior of the native born population of Western European origins.

Holding to this view of a desired social order, Thorndike and other likeminded individuals subscribed to what he labeled a connectionist psychology. This school of thought was in essence a behavioral conception of the relationship between individuals and society. This was essentially a one-way relationship in which individuals were shaped by external stimuli to which they responded. The properly socialized individual was one whose behavior followed the dictates of these external stimuli. In other words, the goals of learning were for individuals to respond to the demands of these external stimuli by behaving in accordance with them. Improper socialization occurred when these same individuals acted in ways counter to these stimuli (Franklin, 1986). Thorndike offered the clearest explanation of how his psychology served as a mechanism of control and regulation in his famous Law of Effect:

Of several responses made to the same situation, those which are accompanied or closely followed by satisfaction to the animal will, other things being equal, be more firmly connected with the situation so that when it recurs, they will be more likely to recur; Those which are accompanied or closely followed by discomfort to the animal will, other things begin equal, have their connection with the situation weakened so that when it recurs, they will be less likely to occur. The greater the satisfaction or discomfort, the greater the strengthen or weakening of the bond (Thorndike, 1911, 15-16).

This psychological principle was effectively Thorndike's statement of what we today call conditioning or behavior modification. There were a number of educational reformers who sought to apply this psychological principal to social organization and the design of schools. In that vein, Thorndike framed his proposals in discourse that advocated increasing the number of able people in the population while decreasing those of less ability. He 
advocated the creation of marriage and child allowances, which would be given to the nation's most intelligent men between the ages of 21 and 30. He believed that the money would enable these men in the prime of their youth to marry women who he believed would be of equally high intelligence and to produce a new generation of able children.

The less able segments of the population should, he argued, be prevented from reproducing. Considering, he pointed out. "the fact that genes which make able and good people also tend to make competent and helpful homes, and the argument for sterilizing anybody near the low end of the scale in intellect and morals whenever it can be done legally is very strong." It was a policy, he pointed out, which would result in a reduction of the number of individual who were institutionalized for mental deficiency as well as a decline in the number of violent crimes and rapes, and it would allow the resources of society to be used for hospital and schools instead of for the custodial care of the genetically defective" (Thorndike, 1940, 458-460).

The educational sociologist, Ross L. Finney (1875-1934) writing at about the same time as Thorndike, saw the same principle as providing a script for the ordering of society under the leadership of those who were most able. They were to be the intellectual leaders who would provide expert knowledge that the masses would mimic. The result would be a homogenous and unified social order. This was to be, as he saw it a process of entrusting leadership to the most intelligent while consigning the majority of the population to "followership" (Finney, 1928, 397). Finney embraced a discourse that saw the schools as the agency for building the kind of community that would ensure this outcome:

Ours are the schools of a democracy, which all the children attend. At lest half of them never had an original idea of any general nature, and never will. But they must behave as if they had sound ideas. Whether these ideas are original or not matters not in the least. It is better to be right than to be original. What the duller half of the population needs, therefore is to have their reflexes conditioned into behavior that is socially suitable. And the wholesale memorizing of catchwords - provided they are sound ones - is the only practical means of establishing bonds in the duller intellects between the findings of social scientists and the corresponding behavior of the masses. Instead of trying to teach dullards to think for themselves, the intellectual leaders must think for them, and drill the results memoriter into their synapses. For the dullards it is that or nothing (Finney, 1928, 395). 
There were others, most notably John Dewey, who took a far less defensive position. Dewey did not fear immigrant groups but welcomed them as a source of fresh ideas and innovative practices that would enrich American society. His understanding of community was one that was built on the mutual adjustment of all segments of society to a commonly agreed on set of values, attitudes, and standards of behavior reflecting the diverse cultural practices of the population. Securing this adjustment and mutuality was the task of a democratic brand of social control that was to be entrusted to a host of social institutions, particularly the schools.

Dewey's starting point was the rural, small town of nineteenth century America where the principal indusial and manufacturing activities of the day were centered in the home. As Dewey saw it, an array of social, economic, and demographic changes in the fifty years following the end of the Civil War and into the early days of the twentieth century led to the separation of the home from the workplace. These changes included the growth of corporate capitalism, the rise of the industrial plan, the movement of settlement from the countryside to the city, and the growing diversity of the population in the wake of immigration.

Under these conditions, Dewey argued, the fact-to-face relationships of the small town gave way to less intimate associations. The independent craftsmen, merchants, and farmers who owned and directed the products of their labor during the early days of the nation were transformed into employees and workers and linked by more distant and remote networks of interdependence. The once vital connections that told individuals who they were, what they did, and how they related to the larger society had become lost as experts assumed responsibility for decisions that were once under popular control. The result, Dewey argued, was the erosion of the ability of ordinary individuals to function as active citizens to resolve the dilemmas that they faced through participating in democratic politics. Their collective identity, which Dewey referred as the "public" had become so dissipated and attenuated that it could no longer address the myriad of problems that they, their families, and their fellow citizens faced.

The remote and distant interpersonal relationships brought about by industrialization and the growth of technology had produced according to Dewey, a "Great Society." It was not, however, the "Great Community" with the robust "public" that he sought. What was missing was the interplay that would allow individuals to shape groups to which belonged while at the same time not limiting the potential of the group to manifest an overriding common purpose (Dewey, 1923). 
As Dewey saw it, the individual did not exist in isolation from other individuals but was a "social being." What joined people together in society and what made democracy possible was the presence of a "common will" that would bring together majority and minority opinion into a unified whole. For Dewey, this relationship between society and its members was a reciprocal one. Individuals were, he believed, a product of the society in which they lived and work. But each individual has a part to play in constructing the elements of that society_-its values, attitudes, and standards of behavior.

\section{IV.}

Although it is often difficult to connect the proposals that educational thinkers make for reforming schools to what actually happens in the schools, we can look to see if we can discern any effects. One of the best and clearest examples of this connection is to be found reforms that Leonard Covello, Principal of Benjamin Franklin High School in introduced New York City during the 1930s to establish a "community school." Covello saw his task as the school's leader as that of extending the school's mission to include the community in which he resided. As he saw it, "the school must enlarge its vision, expand its facilities, and reach forth into community life in order to establish a magnetically intimate contact with the people, their problems, their potential values, and their needs." The extent to which he achieved that goal was, however, limited. There were a number of community programs that operated both inside and outside the school that established this linkage. One involved securing citizen participation through the establishment of a Community Advisory Council (CAC), and a number of Federally funded Works Progress Administration (WPA) initiatives. The CAC was composed of a number of committees that addressed such community problems as health, citizenship, parent education, race, and guidance. These were agencies that were physically located outside the school in storefronts in the surrounding neighborhood that brought community members, businesspersons, parents, teachers, and students together to improve community life. These units included the Association of Parents, Teacher, and Friends whose task was to expand the work of the school in the community, the Friends and Neighbors Club that among other things supported a "friendship" garden and provided meeting space for community groups, and the Italy-American Educational Bureau and the Hispano-American Education Bureau that developed educational programs as well as provided assistance for Italian and Spanish speaking immigrants for getting jobs and gaining 
citizenship. The WPA funded programs included support for a number of initiatives including an array of community oriented research projects, and adult evening and summer school that offered classes in English and citizenship for immigrants, and a remedial reading clinic.

The regular high school program that included both academic and vocational programs was less successful in achieving this connection. Although efforts were made from time to time to integrate content about critical community issues into regular courses, there was no attempt to create a problem-centered curriculum. It remained for the most part a "teacher and subject-centered" one. There was in fact only one course at the high school, the leadership course for high ability students, that was organized around contemporary problems and involved the students in actual community research (Franklin, 2010, 21-22).

Covello's work at Benjamin Franklin was just one of a number of so-called community schools established during this period. Ralph Tyler offered another example like the efforts of Covello in New York City, of how the schools, in this case in Holtville, Alabama, were linking the their work to the problems of the community. One such dilemma, he noted, was the declining productivity of the region's farmers. From their reading and study. From their reading and study, the city's high school students identified a number of ways of increasing yields, such as crop rotation and diversified farming, techniques that they in turn communicated to local farmers. They also learned how check dams might be used to control soil erosion, which was also causing declining productivity, and activity participated in programs for constructing these dams throughout the area. Another problem that Tyler described from Holtville's community school core curriculum was that of nutrition. After studying the diet of local residents, the students suggested a number of ways that farmers could improve the nutrition of local residents, including the production of more diversified crops and the establishment of an area refrigeration facility so that fresh produce and meat could be readily available throughout the year (Franklin, 1988).

It was during the years that Tyler was examining community schools that he would develop an understanding that would guide American curriculum work in the years around World War Two and for another twenty or so years. In a 1942 talk to the parents association of the Dalton School, an independent school in New York City that was a participant in the now famous Eight Year Study, he described curriculum planning as a process for asking first, "what are the chief ends (aims, objectives) that the school must seek to attain" and second what "experiences experience, what material and learning activities are most effective for 
attaining those ends?" Tyler, then, went on to describe three factors that must be taken into account in answering the first question, the external needs of society, the social needs of youth, and the developmental needs of youth. These three factors, he concluded, when examined in light of the "philosophy of the school" would yield the "major aims of the curriculum" (Franklin, 1988, 289). It was an approach to curriculum development that formed the basis of what would become the famous Tyler Rationale for curriculum development that has come to dominate the discourse of curriculum making in the years after 1950 (Tyler, 1950).

V.

Viewing the schools as a means of constructing community has been a powerful discourse for framing curriculum thinking throughout the twentieth century. The major reform movements during the past almost one hundred years - child centered education, social efficiency, social reconstruction, life adjustment education, the discipline centered reform movement, and the standards movement - have all invoked notions of community, unity, and social cohesion as key rationales for curriculum change (Franklin, 2010, Johnson \& Franklin, 2008; Kliebard, 2004).

Community remains today a major discourse in curriculum reform. A recent example is the effort beginning in 1985 and continuing today of the West Philadelphia Improvement Corps (WEPIC), a partnership between the School District of Philadelphia, the University of Pennsylvania, and the neighborhood surrounding the university to improve local schools, build affordable housing, enhance economic develop, expand city services, and reduce crime.

A central feature of the WEPIC initiative is the provision of university support to create a number of community schools in West Philadelphia that bear a striking similarity to the kind of initiative implemented by Covello earlier in the century. The university provides significant financial support for establishing and maintaining these schools as well as involving university faculty, students, and staff in all aspect of their operation including the selection of the curriculum, the teaching of classes, student mentoring, professional development, and the offering of special programs for students and for community residents. As part of its school improvement plan, the university created the Center for Community Partnerships that among other efforts supports the development of service learning courses in which university faculty and students work on experiential projects with students in these neighborhood schools. 
In one such effort, a university course in nutritional anthropology was transformed into a seminar on the relationship between obesity and nutrition that was taught by university students at a neighborhood middle school. The course was designed to enhance student knowledge about nutrition as well as to change their eating habits. As part of the seminar, university and middle school students worked together on evaluating the weight, height, and body mass of middle school students; evaluating their diets; interviewing community families regarding their children's nutrition; observing students' eating habits in the school cafeteria; and determining the sites where various kinds of food were offered in the neighborhood surrounding the school. The project also involved the middle school students in assisting university anthropologists in colleting, organizing, and interpreting nutritional data that they were collecting in the neighborhood. Other similar service learning course introduced in WEPIC schools included a comparative study of Philadelphia and fifth century BC Athens to explore the relationship between community, neighborhood, and family and a course in the study of the nature of American identity. These courses were in effect collaborative endeavors to advance the knowledge and learning of both university and public school students as well as to improve the West Philadelphia neighborhood. This effort like the work of Covello during the 1930s and the other examples we considered in this essay represents an attempt to use the schools as forums to bring individuals together to establish a sense of community around common concerns or issues (Benson. Harkavy, \& Puckett, 2007; Rodin, 2007). What has, however, been left unresolved is the direction that this use of curriculum discourse will take it. Will it direct us toward the liberal brand of community popularized by Dewey or the more reactionary variation advanced by Thorndike and Finney?

\section{References}

Angus, D.L. \& Mirel J.E. (1999). The failed promise of the American High school, 18901995. New York: Teachers College Press.

Benson, L., Harkavy, I., \& Puckett, J. (2007). Dewey's dream: Universities and democracies in an age of education reform: Civil society, public schools, and democratic citizenship. Philadelphia: Temple University Press.

Bounds, E.M (1997). Coming together/coming apart: Religion, community, and modernity. New York: Routledge.

Commission on the Reorganization of Secondary Education (1918). Cardinal principles of secondary education. Bureau of Education Bulletin 1918, no. 35. Washington, D.C. GPO.

Dewey, J. (1923). The public and its problems. New York: Henry Holt. 
Finney, R.L. (1928), A sociological philosophy of education. New York: Macmillan.

Franklin, B.M. (1986). Building the American community: The school curriculum and the search for social control. London: Falmer Press.

Franklin, B.M. (1988). Education for an urban America: Ralph Tyler and the curriculum field. In I. Goodson (ed.), International perspectives in curriculum history (277-296). London: Routledge.

Franklin, B.M. (1994). From backwardness to "at-risk: Childhood learning difficulties and the contradictions of school reform. Albany: State University of New York Press.

Franklin, B.M. (2010). Curriculum, community, and urban school reform. New York: Palgrave Macmillan. http://dx.doi.org/10.1057/9780230105744

Hennessy, R. (1993). Materialist feminism and the politics of discourse. New York: Routledge.

Kliebard, H.M. (2004). The struggle for the American curriculum, $3^{\text {rd }}$. edition New York: RoutledgeFalmer.

Krug, E.A. (1969). The shaping of the American high school, 1880-1920. Madison: The University of Wisconsin Press.

National Education Association (1894). Report of the committee of ten on secondary school studies. New York: American Book Company.

Ravitch, D. (2000). Left Back: A century of failed school reform. New York: Simon \& Schuster

Reese, W.J. (2005). America's public schools: From the common school to "No child left behind," Updated edition. (Baltimore: Johns Hopkins University Press).

Reese, W.J. (1988). "Public schools and the common good." Educational theory, 38, 431440.

Rodin, J. (2007). The university \& urban renewal: Out of the ivory tower and into the schools. Philadelphia: University of Pennsylvania Press.

Tanner, D. \& Tanner, L. (1990). History of the school curriculum. New York: Macmillan.

Thorndike, E.L. (1911). Animal intelligence. New York: Macmillan.

Thorndike, E.L. (1940). Human nature and the social order. New York: Macmillan.

Tyler, R. (1950). Basic principles of curriculum and instruction: Syllabus for Education 205. Chicago: University of Chicago Press. 


\title{
As raízes discursivas da comunidade: uma genealogia do currículo ${ }^{2}$ (Edição bilíngue: inglês/português)
}

The discursive roots of the community: a genealogy of the curriculum Las raíces discursivas de la comunidad: una genealogía del currículo

\author{
BARRY M. FRANKLIN ${ }^{3}$
}

\section{Resumo:}

Este artigo explora discursos construídos em torno do currículo nos Estados Unidos. $O$ periodo destacado se situa entre os anos de 1890 e os primeiros trinta anos do século XX. Destacam-se os documentos produzidos pela National Education Association (NEA) e as formações discursivas delineadas por três indivíduos chave: Edward L. Thorndike, Ross L. Finney e John Dewey. A questão central abordada diz respeito ao currículo como esforço de instituir e perpetuar a vida grupal e a disputa pela ideia de comunidade

Palavras-chave: Currículo, Comunidade, Dewey, Thorndike, Finney.

\section{Abstract:}

\footnotetext{
${ }^{2}$ Tradução realizada por Luiz Ramires Neto, com revisão técnica realizada pela Profa. Dra. Mirian Jorge Warde.

${ }^{3} \mathrm{PhD}$ pela University of Wisconsin-Madison - Professor da School of Teacher Education and Leadership Emma Eccles Jones College of Education and Human Services Utah State University - Major Fields of Interest: 4 curriculum policy, theory, and history urban education educational policy. E-mail: barry.franklin@usu.edu
} 
This article explores discourses constructed about the curriculum in the United States. The highlighted period goes from the 1890s to the first thirty years of the $20^{\text {th }}$ century. Attention is given to the documents produced by the National Education Association (NEA) and the discursive formations outlined by three key individuals: Edward L. Thorndike, Ross L. Finney, and John Dewey. The main issue is about the curriculum as an effort to institute and perpetuate group living and the dispute around the idea of community.

Keywords: Curriculum, Community, Dewey, Thorndike, Finney.

\section{Resumen}

Este artículo explora los discursos construidos en torno del currículo en los Estados Unidos. El periodo destacado se situa entre los años de 1890 y los primeros treinta años del siglo XX. Se destacan los documentos produzidos por la Asociación Nacional de Educación (NEA) y las formaciones discursivas delineadas por tres individuos clave: Edward L. Thorndike, Ross L. Finney y John Dewey. La cuestión abordada considera el currículo como el esfuerzo de instituir y perpetuar la vida grupal y la disputa por la idea de comunidad.

Palabras-clave: Currículo, Comunidad, Dewey, Thorndike, Finney. 
Uma maneira de compreender as políticas e práticas educacionais é explorar os discursos através dos quais enquadramos suas características. Tais discursos representam "aquelas ideias textuais, conceitos e declarações que não apenas fornecem significado, mas constituem sistemas de poder para afetar a organização social e o comportamento humano" (FRANKLIN, 2010, p. 8). Podem incluir, mas não se limitam à sua origem e história, seu propósito e missão, sua ideologia, sua organização, as partes interessadas, sua interação com outras instituições bem como seus pontos fortes e fracos.

O currículo norte-americano é um exemplo ilustrativo e relevante. Uma vez que um curso ou uma sequência de estudo - formal ou informal — é uma propriedade constitutiva dos esforços para instituir e perpetuar a vida grupal em sucessivas gerações, não pode haver um ponto de partida definitivo, universalmente aceito, para tal consideração.

Poderíamos começar nosso relato com os esforços dos colonizadores puritanos do século XVII em prover a socialização e tutela de seus filhos nas novas colônias da América. Poderíamos, contudo, centrar nossa atenção no establishment do movimento pela escola comum de meados do século XIX. Ou poderíamos, como ponto de partida, observar a expansão das escolas primárias também em princípios do século XIX vindo a tomar diferentes formas de educação secundária.

Minha própria preferência neste ensaio é iniciar meu estudo durante a década de 1890 e continuar observando em torno dos primeiros trinta anos do século XX. Selecionei esse período porque esses eram os anos em que a escola secundária abrangente ${ }^{4}$ e urbana, a instituição na qual concentrei minha atenção na maior parte da minha pesquisa, foi moldada através da publicação de relatórios que definiram a natureza, as finalidades e estruturas que a educação secundária norte-americana viria a assumir desde então. Além disso, fiz essa escolha porque esse é mais ou menos o período durante o qual os reformadores educacionais dos EUA definiram o que eu tenho argumentado ser um propósito chave para a escolarização pública, naquele país, a construção de um senso de comunidade entre seus cidadãos.

O ponto de partida para este ensaio é um exame dos discursos que moldaram o entendimento primeiro que os reformadores da escola tinham a respeito da escola secundária abrangente e urbana nos anos ao redor da virada do século XX. Encontrei locais para esses

\footnotetext{
${ }^{4}$ Nota do revisor (NR). Comprehensive high school: Refere-se a um tipo de "high school" pública que oferece um currículo abrangente que o aluno pode compor "segundo seus interesses ou necessidades". Em regra, a "comprehensive high school" oferece mais de um tipo de ensino profissional. Neste artigo, a expressão será também traduzida por escola secundária integral. De uma maneira geral, a "high school" representa a parte superior da escola secundária como era tradicionalmente chamada, dando sequência à escola primária e média ("primary school" e "middle school") e antecedendo o ensino superior.
} 
discursos em dois relatórios da National Education Association (NEA) ${ }^{5}$, o Report of the Committee of Ten $^{6}$ (NATIONAL EDUCATION ASSOCIATION, 1894) desse mesmo ano e o Relatório dos Cardinal Principles of Secondary Education Report ${ }^{7}$, de 1918, da Commission on the Reorganization of Secondary Education ${ }^{8}$ (NATIONAL EDUCATION ASSOCIATION, 1918).

A importância desses relatórios para os fins a que me propus é que eles trouxeram uma percepção da noção de comunidade defendida pelos reformadores da escola daqueles tempos. Tendo apresentado o pensamento comunitário subscrito por esses reformadores, examinarei de que modo organizaram o currículo tornando-o um mecanismo de construção da comunidade. Aqui, prestarei particular atenção às formações discursivas delineadas por três indivíduos chave: Edward L. Thorndike, Ross L. Finney e John Dewey. Uma vez explorados esses discursos, focalizarei o modo como eles se empenharam em inúmeros esforços concretos visando seus programas e propostas para a escola secundária integral. E, finalmente, examinarei o que nosso entendimento desses discursos nos diz a respeito do estado do currículo norte-americano.

Meu relato não é uma história tradicional com uma trajetória linear que liga o currículo atual às suas supostas origens iniciais. Ao invés disso, a história que vou contar está mais na forma de uma genealogia no sentido foucaultiano daquele termo para destacar os importantes discursos que, ao longo do tempo, vieram à tona, recuaram para o segundo plano e emergiram na definição e estruturação do currículo.

\section{II.}

O programa de estudo nas primeiras escolas secundárias nos EUA nos primórdios do século XIX representou uma extensão e uma ampliação do currículo da common school ${ }^{9}$ compreendendo o trabalho para além daquele oferecido nas séries elementares.

Há duas configurações que esse currículo assumiu. Uma foi o currículo clássico, que tinha suas raízes nas ideias educacionais da Grécia e de Roma, na universidade medieval e na Renascença. Em sua forma original compreendia o trivium (Gramática, Retórica e Lógica) e

\footnotetext{
${ }^{5}$ NR. Associação Nacional da Educação.

${ }^{6}$ NR. Relatório do Comitê dos Dez.

${ }^{7}$ NR. Princípios Cardeais da Educação Secundária.

${ }_{9}^{8}$ NR. Comissão pela Reorganização da Educação Secundária.

${ }^{9}$ NR. Common school: a escola pública existente nos EUA do século XIX que oferecia os saberes elementares.
} 
o quadrivium (Aritmética, Geometria, Astronomia e Música). O foco desse programa de estudos tal como aparecia na escola secundária norte-americana do século XIX estava nas línguas clássicas do Latim e Grego e na Aritmética. Esse programa foi concebido para o pequeno número de estudantes que estivessem se preparando para entrar na universidade.

Havia uma segunda e mais popular configuração conhecida como o currículo inglês. Suas raízes se encontram num esforço de tornar o currículo clássico mais prático e relevante para o mundo do comércio e dos negócios e incluía as chamadas "matérias modernas" tais como História, Ciências, Línguas estrangeiras modernas e Literatura.

Algumas versões do currículo inglês também contavam com matérias que tinham uma aplicação vocacional, entre elas Trigonometria e Contabilidade. Em escolas secundárias menores de zona rural, não era incomum encontrar um curso que incluísse Latim juntamente com muitas das matérias que faziam parte do curso inglês. (ANGUS, MIREL, 1999; KRUG, 1964; TANNER, TANNER, 1990).

Defensores da escola secundária ofereceram dois argumentos a favor desses padrões curriculares. Um era o argumento humanista, que foi muito vigorosamente desenvolvido por William Torrey Harris que, nos primórdios de sua carreira, liderou as Escolas Públicas de St. Louis e, posteriormente, atuou como Commissioner of Education ${ }^{10}$ dos EUA. Harris defendia um currículo comum formado por matérias que oferecessem aos alunos acesso aos elementos centrais da herança ocidental do país. Essas matérias constituíam “janelas da alma” e representavam os percursos através dos quais os estudantes seriam infundidos com sua memória cultural.

A Aritmética, argumentava ele, expressa nossa compreensão do quantitativo, a Geografia, nosso entendimento da natureza orgânica e não orgânica; a História, o poder da vontade da nação; a Gramática, os funcionamentos internos da mente; e a Literatura e a Arte, os sentimentos e convicções que nos guiam. A educação para Harris era um processo em que o indivíduo deveria ser socializado nas regras da escola e, mais amplamente, na cultura em geral (KLIEBARD, 2004; REESE, 2000).

A segunda justificativa era a das disciplinas mentais. A finalidade do currículo era o desenvolvimento mental. Era um ponto de vista apoiado pela teoria psicológica dominante daquela época, a psicologia das faculdades mentais. De acordo com esse argumento, a mente

\footnotetext{
${ }^{10}$ NR. Commissioner of Education: Título atribuído ao chefe do Federal Office of Education, historicamente uma unidade dentro do Departamento do Interior dos Estados Unidos. O cargo foi criado em 2 de março de 1867, O primeiro Commissioner of Education foi Henry Barnard (1867-1870); Willian T. Harris (1889-1906) foi o quarto (KNEZEVICH, S. J., 1969), Administration of Public Education (2 ed.), New York: Harper \& Row.
} 
era vista como sendo formada por uma matriz de capacidades mentais tais como o raciocínio, a memória, a observação e o juízo que poderiam, com o devido treinamento, ser desenvolvidas. De modo bastante semelhante a como exercitamos o corpo para desenvolver a força física, exercitamos a mente através do estudo de certas matérias, as quais - de acordo com seus defensores - vinham a ser, convenientemente, as disciplinas abrangidas pelo curso clássico (KLIEBARD, 2004; RAVITCH, 2000).

Uma característica desses argumentos curriculares era a visão do programa escolar como sendo um instrumento para a construção do senso de comunidade ou do propósito comum no seio da população norte-americana. A comunidade, entretanto, é um daqueles conceitos frequentemente rotulado como sendo um significante flutuante ou vazio, apontando para o fato de que se trata de uma palavra desprovida de um único ou específico referente. A teóloga Elizabeth Bounds (1997) ofereceu um tanto do que ela denominou "desejos” para descrever a busca da comunidade. Entre eles estão um anseio pelos que pensam da mesma forma e pela unanimidade, a busca de um passado e de uma época mais simples e um desejo de recuperar o conjunto perdido das tradições em face de perspectivas mais dominantes. Bounds prossegue citando Rosemary Hennessy (1993, p. 14) para falar a respeito da noção de comunidade como "a matriz das práticas produtoras de sentido" que empregamos para descrever a realidade existente. Comunidade, em outras palavras, é um termo que é utilizado de múltiplas maneiras para sugerir com referência à escolarização coisas tais como "objetivos desejáveis [...] como chegar ao bem comum, a colaboração mútua entre colegas, [e] deixar passar despercebidas as diferenças". É uma noção que cumpre "o papel de unir os indivíduos em coletividades de vários tipos" (FRANKLIN, 2010, p. 8-9).

O Comitê dos Dez, que foi organizado em 1892 pela National Education Association (NEA), promoveu esse ideal comunitário em vista do currículo que defendiam. O relatório de 1893 desse comitê requeria quatro programas de estudos para as escolas secundárias: Clássico, Científico-Latim, Línguas Modernas e Inglês. Cada um desses programas abrangia aproximadamente o mesmo padrão de cursos em Inglês, História, Matemática e as Ciências Naturais, mas diferiam em seus requisitos de língua estrangeira (KLIEBARD, 2004; RAVITCH, 2000).

Na elaboração de seu relatório, o Comitê tratou de inúmeras indagações cruciais, cujas respostas ajudaram a definir e estruturar suas recomendações. A mais importante dessas indagações para os nossos propósitos aqui era se uma matéria deveria ser ensinada de forma diferente para os alunos em função de seus planos educacionais ou da carreira após a escola 
secundária. A resposta do Comitê foi negativa. Cada disciplina que é ensinada na escola secundária, argumentava, deve ser lecionada da mesma maneira e com o mesmo conteúdo para todos os alunos (NATIONAL EDUCATION ASSOCIATION, 1894; REESE, 2011). Ao responder a essa pergunta da maneira como o fizeram, o Comitê estava asseverando o apoio ao ideal de uma escola comum para todos. Embora tal princípio nunca tenha sido completamente efetivado nas escolas dos EUA, ele defende que se deve oferecer a todas as crianças as mesmas experiências educacionais nos mesmos ambientes (FRANKLIN, 1994; REESE, 1988).

Um tema comunitário também foi inserido no relatório da Comissão pela Reorganização da Educação Secundária, Os Princípios Cardeais da Educação Secundária. No âmago desse relatório havia um conjunto de sete objetivos. Tais objetivos_- "saúde, comando dos processos fundamentais, pertencimento a um lar digno, vocação, cidadania, uso digno do lazer e caráter ético" (COMMISSION ON THE REORGANIZATION OF SECONDARY EDUCATION, 1918, p. 5) - deveriam ser as metas a serem proporcionadas a todos os estudantes. O tema da comunidade se fez sentir mais claramente no relatório nos esforços de seus autores em vincular a escolarização aos ideais de democracia. Tais ideais exigem que os indivíduos e grupos atinjam metas vocacionais especializadas que são necessárias ao progressivo desenvolvimento do país enquanto simultaneamente se unificam. O relatório prossegue dizendo que "se não houver unificação numa democracia, não poderá haver uma vida comunitária digna bem como não haverá ação concertada rumos aos fins sociais necessários" (COMMISSION ON THE REORGANIZATION OF SECONDARY EDUCATION, 1918, p. 15).

O caminho para chegar a esses dois fins, de acordo com os autores do relatório, era a escola secundária integral que proporcionava "todos os currículos numa única organização unificada". Havia elementos do currículo conhecidos como constantes que possibilitariam o cumprimento das sete metas da escola secundária. Havia variáveis do currículo cujo objetivo era prover as necessidades vocacionais dos alunos. E havia também optativas livres que permitiriam aos estudantes perseguir seus interesses específicos (COMMISSION ON THE REORGANIZATION OF SECONDARY EDUCATION, 1918, p. 18-19). Tal como os autores do relatório viam a questão, a escola secundária para todos era o melhor mecanismo para se atingir a unificação exigida por uma democracia: 
Através das amizades formadas com alunos seguindo outros currículos e tendo objetivos vocacionais e educacionais bem diferentes dos seus próprios, os estudantes se dão conta de que os interesses que eles têm em comum uns com outros, afinal, são muito mais importantes que as diferenças que tenderia a torná-los antagonistas aos demais. Por meio da organização e das assembleias escolares, eles adquirem ideias comuns. Através das atividades em grupo, asseguram o treinamento para agir colaborativamente. Por meio da lealdade a uma escola, que abrange muitos grupos, são preparados para a lealdade ao Estado e à Nação. Em suma, a escola para todos é o protótipo de uma democracia na qual os diversos grupos devem ter um grau de autoconsciência de serem grupos e ainda se federarem num todo maior através do reconhecimento de interesses e ideais comuns (COMMISSION ON THE REORGANIZATION OF SECONDARY EDUCATION, 1918, p. 20).

III.

Como observado anteriormente, os reformadores norte-americanos da escola, nos anos em torno da virada do século XX, utilizaram a noção de comunidade de formas diversas e conflitivas. Aqueles de tendência conservadora - sendo o psicólogo norte-americano Edward A. Thorndike (1874-1949) um excelente exemplo - utilizaram o termo de uma maneira excludente para apontar aquelas características que separam os indivíduos e grupos entre si, entre elas as diferenças de língua ou linguagem, de religiões, de etnia e de cultura.

Falar sobre comunidade dessa forma serve primeiro para limitar o pertencimento de certos indivíduos e grupos e, uma vez feito isso, para constrangê-los, isolá-los e até mesmo eliminá-los. Embora um traço da noção de comunidade que é visto favoravelmente pelos que estão dentro dela e são parte dela, permite que a mesma seja invocada para legitimar o racismo, o sexismo e uma miríade de outras formas de controle e exclusão. Thorndike e outros intelectuais norte-americanos do início do século XX usaram essa compreensão da noção de comunidade para se opor ao aumento no país de imigrantes vindos do Leste e do Sul da Europa. Viam esse aumento da imigração como constituindo uma ameaça à estabilidade da sociedade norte-americana e, em última instância, à própria democracia. Para eles, a ideia de comunidade era uma noção defensiva engendrada para frear o deslocamento e perturbação sociais que identificavam com a crescente diversidade da população dos EUA. Para combater essa ameaça, propuseram esforços visando restringir a imigração. Mais do que tentar impedir 
que tais imigrantes entrassem no país, propunham utilizar as escolas e outras instituições sociais como mecanismos de controle social para instilar nestes imigrantes o que consideravam como sendo os valores e atitudes corretos. O que buscavam era uma comunidade norte-americana homogênea e que partilhasse os mesmos pontos de vista enraizada nos valores, crenças e padrões de comportamento da população nativa, de origens europeias ocidentais.

Apegado a essa visão de uma ordem social desejada, Thorndike e outros indivíduos com convicções afins subscreviam o que ele denominou de uma psicologia conexionista. Essa escola de pensamento era, essencialmente, uma concepção comportamental da relação entre indivíduos e sociedade. Isso era, basicamente, uma relação de mão única na qual os indivíduos eram formados pelos estímulos externos aos quais reagiam. O indivíduo adequadamente socializado era aquele cujo comportamento seguia os ditames dos estímulos externos. Em outras palavras, os objetivos da aprendizagem eram que os indivíduos respondessem às demandas desses estímulos externos manifestando um comportamento em consonância com os mesmos. A socialização incorreta ou inadequada ocorria quando esses indivíduos agiam de maneiras contrárias àqueles estímulos (Franklin, 1986).

Thorndike ofereceu a mais clara explicação de que modo esta psicologia servia como mecanismo de controle e regulação em sua famosa Lei do Efeito:

Das diversas respostas dadas à mesma situação, aquelas que são acompanhadas ou seguidas de perto pela satisfação do animal serão mantidas as mesmas condições, conectados com mais firmeza à situação de modo que, quando ocorrer, será mais provável que se repita; os que são acompanhados ou seguidos de perto por desconforto do animal terão, mantidas as mesmas condições, sua conexão com a situação enfraquecida de modo que quando ela se repetir, será menos provável que ocorra. Quanto maior a satisfação ou desconforto, maior a força ou o enfraquecimento do elo (THORNDIKE, 1911, p. 15-16).

Esse princípio psicológico foi efetivamente a declaração de Thorndike quanto ao que hoje denominamos condicionamento ou modificação comportamental.

Havia numerosos reformadores educacionais que procuravam aplicar esse princípio psicológico à organização social e à concepção das escolas. Nessa vertente, Thorndike emoldurou suas propostas no discurso que defendia o aumento do número de pessoas capazes na população ao mesmo tempo em que diminuísse a quantidade dos menos capazes. Defendia 
a criação de subsídios financeiros para o casamento e filhos, que seria concedido aos homens mais inteligentes do país na faixa etária entre 21 e 30 anos. Ele acreditava que o dinheiro permitiria que estes homens na flor de sua juventude se casassem com mulheres que Thorndike achava que teriam inteligência tão elevada quanto à dos homens e que assim produziriam uma nova geração de crianças capazes.

Os segmentos menos capazes da população deveriam, argumentava ele, ser impedidos de se reproduzir. Considerando, salientava ele, "o fato de que os genes que fazem com que as pessoas sejam boas e capazes também tendem a constituir lares competentes e prestativos, e o argumento pela esterilização de qualquer um que esteja próximo ao extremo inferior da escala de intelecto e moralidade sempre que seja possível realizar isto legalmente é muito forte”. Era uma política, destacava ele, que resultaria numa redução no número de indivíduos que fossem institucionalizados por causa de deficiência mental bem como haveria um declínio no número de crimes violentos e estupros, e permitiria que os recursos da sociedade fossem utilizados por hospitais e escolas e não para a internação dos geneticamente defeituosos" (THORNDIKE, 1940, p. 458-460).

O sociólogo da educação, Ross L. Finney (1875-1934), escrevendo mais ou menos na mesma época que Thorndike, via o mesmo princípio como proporcionando um roteiro para a ordenação da sociedade sob a liderança daqueles que eram os mais capazes. Esses viriam a ser os líderes intelectuais que proporcionariam o conhecimento especializado que as massas imitariam. O resultado seria uma ordem social homogênea e unificada. Esse deveria ser, na visão dele, um processo no qual se confiaria a liderança aos mais inteligentes enquanto se destinaria a maioria da população ao "seguidismo" (FINNEY, 1928, p. 397). Finney adotou um discurso que via as escolas como a agência para a construção do tipo de comunidade que asseguraria esse resultado:

As nossas são escolas de uma democracia, frequentadas por todas as crianças. Ao menos metade delas nunca teve uma ideia original de qualquer natureza geral, e nunca terá. Mas devem comportar-se como se tivessem ideias saudáveis. Não tem qualquer importância se estas ideias são originais ou não. É melhor ter razão do que ser original. O que a metade mais estupida da população necessita, portanto, é ter seus reflexos condicionados ao comportamento que é socialmente apropriado. E a memorização maciça de slogans - contanto que sejam saudáveis - é o único meio prático de estabelecer elos nos intelectos mais lentos entre as descobertas dos cientistas sociais e o correspondente comportamento das 
massas. Ao invés de tentar ensinar os de mente fraca a pensar por si mesmos, os líderes intelectuais devem pensar por eles e exercitar os resultados memorizando-os em suas sinapses. Para os de mente fraca, é isso ou nada (FINNEY, 1928, p. 395).

Havia outros que assumiram uma posição bem menos defensiva; sendo John Dewey o mais notável. Dewey não temia os grupos imigrantes, mas os acolhia como uma fonte de ideias renovadas e práticas inovadoras que enriqueceriam a sociedade norte-americana. O modo como compreendia a comunidade era aquele construído sobre o ajuste mútuo de todos os segmentos da sociedade a um conjunto definido em comum acordo de valores, atitudes e padrões de comportamento que refletissem a diversidade de práticas culturais da população. Assegurar esse ajustamento e mutualidade era a tarefa de um estilo democrático de controle social que deveria ser confiado a uma miríade de instituições sociais, particularmente as escolas.

O ponto de partida de Dewey era a pequena cidade rural dos EUA do século XIX na qual as principais atividades industriais e de manufatura da época estavam centradas no lar. Na visão de Dewey, um conjunto de transformações sociais, econômicas e demográficas nos cinquenta anos após o término da Guerra Civil e nos primeiros anos do século XX levou a uma separação entre o ambiente doméstico e o local de trabalho. Entre essas mudanças estavam o crescimento do capitalismo corporativo, a ascensão do plano industrial, o movimento de migração do campo para a cidade e a crescente diversidade da população no rastro da imigração.

Sob tais condições, argumentava Dewey, as relações face-a-face da cidade pequena cediam lugar a associações menos íntimas. Os artesãos, comerciantes e agricultores independentes que eram donos e dirigiam os produtos de seu trabalho durante os primórdios da nação foram transformados em empregados e trabalhadores e conectados por redes mais distantes e remotas de interdependência. As conexões antes vitais que revelavam aos indivíduos quem eles eram, o que faziam e como se relacionavam com a sociedade abrangente se perderam à medida que especialistas assumiam a responsabilidade por decisões que antes estavam sob o controle popular. O resultado, argumentava Dewey, era a erosão da capacidade dos indivíduos comuns de funcionar como cidadãos ativos a fim de solucionar os dilemas que enfrentavam através de sua participação na política democrática. Sua identidade coletiva, que Dewey chamava de "o público" havia se tornado tão desgastada e atenuada que não poderia mais dar conta da miríade de problemas que eles, suas famílias e seus concidadãos enfrentavam. 
As relações interpessoais remotas e distantes introduzidas pela industrialização e o avanço da tecnologia havia produzido, segundo Dewey, uma "Grande Sociedade". Não era, entretanto, a "Grande Comunidade" com o "o público" robusto que ele buscava. O que faltava era a interação que permitiria que os indivíduos formassem e moldassem os grupos aos quais pertenciam e que, simultaneamente, não limitassem o potencial do grupo em manifestar um propósito comum primordial (Dewey, 1923).

Na visão de Dewey, o indivíduo não existia isolado dos outros indivíduos, mas como um "ser social". O que unia as pessoas numa sociedade e o que tornava a democracia possível era a presença de uma "vontade comum" que juntaria a opinião da maioria e da minoria num todo unificado. Para Dewey, a relação entre a sociedade e seus integrantes era recíproca. Os indivíduos eram, acreditava ele, produto da sociedade na qual viviam e trabalhavam. Mas cada indivíduo tinha um papel a cumprir na construção dos elementos daquela sociedade — seus valores, atitudes e padrões de comportamento.

IV.

Embora seja frequentemente difícil relacionar as propostas que os pensadores educacionais fazem visando reformar as escolas como aquilo que de fato acontece nas mesmas, podemos tentar verificar se conseguimos discernir alguns efeitos. Um dos melhores e mais claros exemplos desta conexão encontra-se nas reformas que Leonard Covello, Diretor da Benjamin Franklin High School introduziu na cidade de Nova York durante os anos 1930 para criar uma "escola da comunidade". Covello encarou esta tarefa, enquanto líder de uma escola, como sendo a ampliação da missão da escola a fim de incluir a comunidade na qual ele residia. Em sua opinião, "a escola deve alargar sua visão, expandir suas instalações e ir ao encontro da vida comunitária a fim de estabelecer um contato magneticamente íntimo com as pessoas, seus problemas, seus potenciais valores e suas necessidades". O seu êxito em alcançar este objetivo foi, entretanto, limitado.

Havia vários programas voltados à comunidade que atuavam tanto dentro quanto fora da escola e que criavam este elo. Um destes programas visava assegurar a participação cidadã através da criação de um Community Advisory Council $(\mathrm{CAC})^{11} \mathrm{e}$ diversas iniciativas da

\footnotetext{
${ }^{11}$ NR. Conselho Consultivo Comunitário.
} 
Federally funded Works Progress Administration (WPA) ${ }^{12}$ financiadas pelo governo federal. O CAC era formado por diversos comitês que tratavam dos problemas dessa comunidade tais como saúde, cidadania, educação de pais, raça e orientação. Essas eram agências que estavam localizadas fisicamente fora da escola em fachadas de lojas na vizinhança do entorno e que reuniam membros da comunidade, empresários, pais e mães, professores e estudantes a fim de aprimorar a vida da comunidade. Entre estas unidades estavam a Associação de Pais, Mestres e Amigos cuja tarefa era ampliar o trabalho da escola na comunidade, os Clube dos Amigos e Vizinhos que, entre outras coisas, apoiava um jardim da "amizade" e fornecia o local de reuniões para os grupos da comunidade e o Escritório Educacional Ítalo-Americano que desenvolvia programas educativos bem como prestava assistência a imigrantes de língua italiana ou espanhola em busca de empregos e obtenção da cidadania. Entre os programas financiados pela WPA estava o apoio a diversas iniciativas, inclusive um conjunto de Projetos de pesquisa voltados à comunidade, bem como escola de verão e escola noturna para adultos que oferecia aulas de inglês e cidadania para imigrantes, bem como uma clínica de leitura terapêutica.

O programa da escola secundária regular que abrangia tanto programas acadêmicos quanto vocacionais teve menos sucesso em estabelecer esta conexão. Embora fossem empreendidos esforços constantes para integrar o conteúdo de assuntos críticos da comunidade nos cursos regulares, não houve tentativa de criar um currículo direcionado aos problemas. Permaneceu sendo basicamente um currículo "centrado nas disciplinas e nos professores". Houve de fato um único curso na escola secundária, o curso de liderança para estudantes com altas habilidades, que foi organizado em torno de problemas contemporâneos e que envolvia os estudantes em pesquisa real junto à comunidade (FRANKLIN, 2010, p. 2122).

O trabalho de Covello na escola Benjamin Franklin foi apenas um numa multiplicidade das chamadas "escolas da comunidade", criadas durante este período. Ralph Tyler ofereceu outro exemplo semelhante aos esforços de Covello na cidade de Nova York, ilustrando como as escolas, agora as de Holtville, Alabama, estavam relacionando seu trabalho aos problemas da comunidade. Um de tais dilemas, observou, era o declínio da produtividade dos agricultores da região. A partir de sua leitura e estudos, os alunos da escola secundária da cidade identificaram diversas maneiras de aumentar as colheitas, tais como a

\footnotetext{
${ }^{12}$ NR. Administração para o Progresso de Ações Sociais.
} 
rotatividade do plantio e agricultura diversificada, técnicas que eles, por sua vez, divulgavam entre os agricultores locais. Também aprenderam de que modo poder-se-ia utilizar açudes para controlar a erosão do solo, que também estava causando a diminuição da produtividade. Participavam também ativamente de programas destinados à construção destes açudes em toda a região.

Outro problema que Tyler descreveu a partir do currículo essencial da escola comunitária de Holtville foi o da nutrição. Após estudar a dieta dos moradores locais, os estudantes sugeriram diversas formas pelas quais os agricultores poderiam aprimorar os hábitos alimentares da população daquela região, entre elas a produção de cultivos mais diversificados e a criação de um local para a refrigeração de seus produtos de modo que estes, ainda frescos, juntamente com a carne fossem facilmente disponilizados o ano inteiro (FRANKLIN, 1988).

Foi na época em que Tyler estava pesquisando as escolas comunitárias que ele desenvolveria uma compreensão balizadora do trabalho curricular norte-americano nos anos anteriores à II Guerra Mundial e que se estenderia por 20 anos ou mais. Numa fala em 1942 para a associação de pais da Dalton School, uma escola independente da cidade de Nova York que participava do agora famoso Estudo de Oito Anos, Tyler descreveu o planejamento do currículo como sendo um processo indagar primeiramente "quais são os fins primordiais (isto é, os alvos, os objetivos) que a escola deve buscar atingir" e, em segundo lugar, "quais experiências, que materiais e que atividades didáticas são mais eficazes para se atingir tais fins? " Tyler, então, prosseguiu descrevendo três fatores que deveriam ser levados em conta ao se responder à primeira pergunta, as necessidades externas da sociedade, bem como as necessidades sociais e de desenvolvimento da juventude. Estes três fatores, concluía ele, quando examinados à luz da "filosofia da escola" resultariam nos "principais alvos do currículo" (Franklin, 1988, 289). Era uma abordagem do desenvolvimento do currículo que formava a base do que viria a se tornar, para este fim, o famoso Argumento de Tyler que prevaleceria no discurso sobre a construção do currículo nos anos posteriores a 1950 (TYLER, 1950).

V. 
Ver as escolas como um meio de construção de uma comunidade representou um discurso poderoso na concepção do currículo ao longo de todo o século XX. Os principais movimentos de reforma educacional dos quase 100 anos passados - educação centrada na criança, eficiência social, reconstrução social, educação para ajustamento da vida, o movimento de reforma centrado nas disciplinas e o movimento dos padrões educacionais invocaram todos eles as noções de comunidade, unidade e coesão social como argumentos fundamentais para propor a mudança curricular (FRANKLIN, 2010; JOHNSON, FRANKLIN, 2008; KLIEBARD, 2004).

A noção de comunidade permanece ainda hoje um elemento de peso no discurso pela reforma do currículo. Um exemplo recente é o esforço iniciado em 1985 e que prossegue até nossos dias do West Philadelphia Improvement Corps (WEPIC) ${ }^{13}$, uma parceria entre o Distrito Escolar da Filadélfia, a Universidade da Pensilvânia e os bairros vizinhos no entorno do campus que visa melhorar as escolas locais, construir moradia acessível, incrementar o desenvolvimento econômico, ampliar os serviços municipais e reduzir a criminalidade.

Uma característica central da iniciativa do WEPIC é o apoio prestado pela universidade para a criação de diversas escolas comunitárias na parte Oeste da cidade de Filadélfia, algo que carrega impressionante semelhança com a iniciativa levada a cabo por Covello no início do século passado. A universidade fornece robusto apoio financeiro visando a criação e manutenção destas escolas bem como envolve o seu corpo docente, estudantes e funcionários em todos os aspectos de seu funcionamento, inclusive a escolha do currículo, a regência de classes, o aconselhamento dos alunos, o desenvolvimento profissional e a oferta de programas especiais para alunos e moradores da comunidade. Como parte do seu plano de melhoria das escolas, a universidade criou o Centro de Parcerias Comunitárias que, entre outros esforços, apoia a elaboração de cursos de habilidades em serviços. Neles, o corpo docente e os estudantes da universidade atuam em projetos experimentais com alunos destas escolas nos bairros vizinhos.

No âmbito desta iniciativa, um curso de Antropologia nutricional, oferecido pela universidade, foi transformado num seminário sobre a relação entre obesidade e alimentação, tendo sido ministrado por graduandos numa escola média das redondezas. O curso foi concebido visando aumentar e melhorar os conhecimentos dos alunos sobre nutrição bem como modificar seus hábitos alimentares. Como parte do seminário, estudantes universitários

\footnotetext{
${ }^{13}$ NR. Organismo para o aprimoramento da região Oeste da Filadélfia.
} 
e secundaristas atuaram conjuntamente na obtenção do peso, altura e massa corporal de alunos do Ensino Médio; avaliação de suas dietas; entrevistas com famílias da comunidade sobre a nutrição de seus fillhos; observação dos hábitos alimentares no refeitório das escolas; e determinação dos locais em que diversos tipos de alimentos eram oferecidos no entrono de cada escola.

O projeto também envolveu estudantes secundaristas que auxiliariam antropólogos na coleta, organização e interpretação dos dados nutricionais que estavam sendo coletados naquela região. Outro curso semelhante, introduzido nas escolas com WEPIC, fez um estudo comparativo entre a cidade da cidade de Filadélfia e a Atenas do séc. V a.C. com o intuito de explorar a relação entre comunidade, vizinhança e família; houve também um curso que investigou o caráter da identidade norte-americana. Esses cursos foram, de fato, iniciativas colaborativas que pretendiam avançar o conhecimento e a aprendizagem tanto dos estudantes universitários quanto dos alunos das escolas públicas bem como trazer melhorias à região Oeste da Filadélfia. Esse esforço, à semelhança do trabalho desenvolvido por Covello na década de 1930 e outros exemplos apresentados neste ensaio, representa uma tentativa de pensar as escolas como fóruns onde se reúnem indivíduos que criam um senso de comunidade em torno de preocupações ou questões compartilhadas (BENSON, HARKAVY, PUCKETT, 2007; RODIN, 2007). O que, entretanto, permaneceu sem solução é a direção que esse uso do discurso sobre o currículo irá tomar. Irá nos conduzir ao estilo liberal de comunidade, tal como popularizada por Dewey ou nos levará à variação reacionária proposta por Thorndike e Finney?

\section{Referências}

ANGUS, D. L. MIREL J. E. The failed promise of the American High school, 1890-1995. New York: Teachers College Press, 1999.

BENSON, L., HARKAVY, I., PUCKETT, J. Dewey's dream: Universities and democracies in an age of education reform: Civil society, public schools, and democratic citizenship. Philadelphia: Temple University Press, 2007.

BOUNDS, E.M Coming together/coming apart: Religion, community, and modernity. New York: Routledge, 1997.

COMMISSION ON THE REORGANIZATION of Secondary Education. Cardinal principles of secondary education. Bureau of Education Bulletin 1918, no. 35. Washington, D.C. GPO, 1918 
DEWEY, J. The public and its problems. New York: Henry Holt, 1923.

FINNEY, R. L. A sociological philosophy of education. New York: Macmillan, 1928.

FRANKLIN, B. M. Building the American community: The school curriculum and the search for social control. London: Falmer Press, 1986.

FRANKLIN, B. M. Education for an urban America: Ralph Tyler and the curriculum field. In: GOODSON, I. (ed.). International perspectives in curriculum history. London: Routledge, p. 277-296.

FRANKLIN, B. M. From backwardness to "at-risk: Childhood learning difficulties and the contradictions of school reform. Albany: State University of New York Press, 1994.

FRANKLIN, B. M. Curriculum, community, and urban school reform. New York: Palgrave Macmillan, 2010. http://dx.doi.org/10.1057/9780230105744

HENNESSY, R. Materialist feminism and the politics of discourse. New York: Routledge, 1993.

KLIEBARD, H. M. The struggle for the American curriculum, $3^{\text {rd }}$. ed. New York: RoutledgeFalmer, 2004.

KRUG, E. A. The shaping of the American high school, 1880-1920. Madison: The University of Wisconsin Press, 1969.

NATIONAL EDUCATION ASSOCIATION. Report of the committee of ten on secondary school studies. New York: American Book Company, 1894.

RAVITCH, D. Left Back: A century of failed school reform. New York: Simon \& Schuster, 2000.

REESE, W. J. America's public schools: From the common school to "No child left behind", Updated edition. Baltimore: Johns Hopkins University Press, 2005.

REESE, W. J. "Public schools and the common good." Educational theory, [S.1.], n. 38, p, 431-440, 1988.

RODIN, J. The university \& urban renewal: Out of the ivory tower and into the schools. Philadelphia: University of Pennsylvania Press, 2007.

TANNER, D., TANNER, L. History of the school curriculum. New York: Macmillan, 1990.

THORNDIKE, E. L. Animal intelligence. New York: Macmillan, 1911.

THORNDIKE, E. L. Human nature and the social order. New York: Macmillan, 1940. http://dx.doi.org/10.1037/14654-000

TYLER, R. Basic principles of curriculum and instruction: Syllabus for Education 205. Chicago: University of Chicago Press, 1950. 